\title{
Psychosocial status and attitudes of healthcare workers amid the COVID-19 pandemic
}

\author{
Ercan Kurt \\ Adiyaman Training and Research Hospital \\ Ibrahim Ethem Ovalı \\ Mardin Kiziltepe Public Hospital \\ Umut Gulacti ( $\nabla$ umutgulacti@gmail.com ) \\ Adiyaman University \\ Semih Canpolat \\ Adıyaman Gerger Public Hospital \\ Mehtap Koparal \\ Adiyaman Training and Research Hospital \\ Hüseyin Kafadar \\ Adiyaman University \\ Hakan Kaya \\ Adiyaman University \\ Şeyho Cem Yucetas \\ Adiyaman University
}

\section{Research Article}

Keywords: Covid 19, mental health, healthcare workers, Physicians, Non-physicians

Posted Date: June 14th, 2021

DOI: https://doi.org/10.21203/rs.3.rs-40091/v2

License: (c) (i) This work is licensed under a Creative Commons Attribution 4.0 International License. Read Full License

Version of Record: A version of this preprint was published at Journal of Surgery and Medicine on March 1st, 2021. See the published version at https://doi.org/10.28982/josam.860273. 


\section{Abstract}

Background/Aim: COVID-19 disease occurs in close contact due to its highly contagious nature. Healthcare workers (HCWs) are in the frontline of struggling with the COVID-19 pandemic. The thoughts, behaviors, attitudes, and psychosocial statuses of healthcare professionals working in this problematic condition have not yet been fully investigated in Turkey. We aimed to evaluate the mental health and psychosocial status, thoughts about the measures taken by the government, attitudes, and behaviors of healthcare workers facing the COVID-19 pandemic, and whether there is a difference between physician and non-physician HCWs.

Methods: In this cross-sectional survey, a 56-question multiple-choice test created based on similar surveys and scales was performed by a one-to-one interview with the HCWs in three registered hospitals fighting the COVID-19 pandemic from 20 May to 10 June 2020. Mental health variables were assessed via the Patient Health Questionnaire-4 (PHQ-4) and the Turkish Beck Depression Scale to specify psychological manifestations. A scoring system was applied using a four-point Likert scale, from no points ("strongly disagree") to three points ("strongly agree") to determine the levels of anxiety and depression. Participants were divided into two groups as physician and non-physician HCWs for subgroup analysis.

Results: A total of $300 \mathrm{HCWs}$ (45 physicians, 255 non-physician health care workers) enrolled in the survey. Only $0.8 \%$ of HCWs received psychological support from a therapist or psychiatrist. The most common concern during the COVID-19 pandemic was about "the elderly and other risky population being infected" (37.9\%). Compared with non-physician HCWs, physicians felt more concerned about the spread of COVID-19 ( $80 \%$ vs $47.1 \%, P=0.006 \times 2=12.591)$ and they agreed at a higher rate that the number of tests performed was sufficient ( $53.3 \%$ vs. $41.2 \%, P=0.030$, OR: $0.29-0.35, \chi 2=7.047)$. For all HCWs, the "feeling of being infected with COVID-19" item had the highest mean total score (2.60 (0.97). The mean score of the "feeling nervous/anxious/on edge" item was $2.53(0.52)$ for physicians and $2.26(0.86)$ for non-physician HCWs. Non- physicians HCWs had a higher mean score for "Feeling of increased body pain and agony" item than physicians $0.27(0.80)$ vs 0.76 (1.23), mean dif $=-0.50,95 \%$ confidence interval $=-1.002$ to $0.006, P<0.05)$.

Conclusions: The results of this study showed that healthcare professionals were most anxious about "being infected with COVID-19". Both physician and non-physician HCWs were feeling nervous/anxious/on edge according to anxiety scores.

\section{Introduction}

Coronaviridea is enveloped non-segmented, single-stranded RNA viruses. Viruses replicate in epithelial cells of the upper respiratory tract and then in some circumstances spread to the lower respiratory tract. The disease is usually limited to the upper respiratory tract; however, they may cause bronchiolitis, pneumonia, and even acute respiratory distress syndrome. Human coronaviruses were recognized since the 1960s, but in 2003 a novel coronavirus was introduced as an etiologic agent of the outbreak of severe acute respiratory syndrome (SARS). It was announced that the outbreak in Jeddah, Kingdom of Saudi Arabia in June 2012 was named "Middle East Respiratory Syndrome" (MERS) and caused by Middle East Respiratory Syndrome-coronavirus (MERS-CoV) (1). A Pneumonia cluster of unknown cause was observed in Wuhan province, China, in December 2019 and, in January 2020. After testing the samples collected from these patients, it was understood that the cause was a novel coronavirus originated from coronaviruses families such as SARS and MERS and named as Novel Coronavirus 2019 ((2019-nCoV). This novel, the very infectious virus spread all over the world rapidly in a short period. Over 4 million cases and 275 thousand deaths have been reported until now (15/20). The first case in Turkey was observed on 11 March 2020 and over 140 thousand cases and 4 thousand deaths had been reported since then. (15/2020) (2)

Coronaviridea may cause severe respiratory infections especially in elderly and infants and in patients with underlying chronic diseases (1). It spreads mainly via small droplets produced during coughing, sneezing, or talking, and when people are in close contact (3). Although the incubation period is not precisely known, it is estimated between 9 to 12 days when transmitted between humans. This period is noted as approximately 2 days for other infections caused by coronaviruses (4). Based on these assumptions, the observation period of 14 days in Covid-19 is considered to be safe (5).

Covid-19 cases can be seen individually and/or as a group. The cluster of COVID-19 infections can be seen in a family or public health agency. Healthcare workers (HCWs) are in the frontline of struggling with any diseases and play a key role in response to this pandemic as well as the other epidemics. Healthcare professions such as physicians, nurses, and other auxiliary staff, are all under risk because of the very infectious nature of the COVID-19 when close contact occurs. While they all have been working in these circumstances, their thoughts and behaviors have not been fully investigated. Diminishing anxiety levels of HCWs as much as possible might help them fight with pandemic more effectively. In this prospective questionnaire, we aimed to detect the anxiety levels, thoughts, attitudes, and behaviors of HCWs facing the Covid-19 pandemic.

\section{Material And Methods}


This study was designed based on the American Association for Public Opinion Research (AAPOR) guideline for survey studies. The study was approved by the Scientific Committee of Ministery of Health and Adıyaman University Local Ethics Committee. Inform consent was taken from all participants before the questionnaire. Participants are allowed to be free to withdraw the study any time they want and confidentiality of data is paid great attention.

This study is a multi-centered, cross-sectional questionnaire survey study performed by a one- to-one interview with the HCWs registered in the pandemic workforce in Adıyaman University of Training and Research Hospital, Gerger and Kızıltepe Public Hospitals, Turkey, between 20 May 2020 and 10 June 2020. We performed a questionnaire including 56 questions to the volunteers.

\section{Measurements:}

Demographic variables such as gender, age, profession (physician, nurse, administrative personnel, auxiliary personnel, other personnel), marital status (married, single, divorced) were asked in the questionnaire. Besides, the participants were asked whether they had any organic diseases, insomnia, or psychiatric symptoms.

The factors during the Covid-19 outbreak that affect their anxiety levels are asked to be ordered according to their importance.

Questions using a 4-point Likert scale are prepared to determine the participants' self- preservation from Covid-19, attitudes, behaviors, and opinions on preventions taken by the government.

Survey questions are classified to determine the anxiety and depression levels, attributes, and behaviors of HCWs due to the Covid-19 outbreak. Patient Health Questionnaire-4 (PHQ-4) and Turkish Beck Depression Scale are modified and survey questions are established to specify psychological manifestations (Feeling nervous/anxious/on edge, not being able to stop worrying, loss in the joy of leaving, feeling increased risk to get infected, feeling of avoidance from crowds, loss of interest in following news, difficulty in falling asleep, feeling of increased general body pain, feeling down/depressed/hopeless). $(5,6)$ A scoring system was applied using a four-point Likert scale, from no points ("strongly disagree") to three points ("strongly agree") to determine the levels of anxiety and depression.

Survey reliability was tested using Cronbach's alpha and for survey items of psychological manifestations, Cronbach's alpha was 0.65 .

\section{Statistical analyses}

All data analysis was done by using Statistical Package for the Social Sciences software (SPSS 17.0 v). Categorical values were described as percentage and number; numeric values were presented as mean \pm Standard deviation (SD). The categorical variables were compared with the $\chi 2$ test. The student's t-test was performed on each group to compare the differences between mean values. The variant analysis was done by the Levene test. For all statistical analyses, a P-value of $<0.05$ was considered statistically significant.

\section{Results}

\section{Sociodemographic findings and knowledge levels:}

A total of $300 \mathrm{HCW}$ s enrolled in the study and questionnaire were obtained by a one- to-one interview. Of HCWs enrolled in this study, $15 \%$ $(n=45)$ were physicians, $85 \%(n=255)$ were nonphysician health-care workers $(71 \%$ nurse, $9 \%$ staff, $5 \%$ administrative personnel). Of all participants, $50 \%$ were male, $64 \%$ were married, and most of the participants were aged between 26 and 40 . All participants aged between 50 and 65 were physicians. Eighty-six percent of the participants had no history of any kind of illnesses and there was no difference between professions regarding health problems $(P=0.936, \chi 2=0.007)$.

During the Covid-19 pandemic, $68 \%$ of HCWs thought that they had sufficient knowledge about the course of the outbreak and $21 \%$ thought their knowledge was at the expert level. While $53.3 \%$ of physicians thought that they knew at the expert level, this ratio was $15.3 \%$ in the nonphysician HCWs $(\mathrm{P}=0.004, \chi 2=11.121)$. Of all HCWs, $85 \%$ have not done any research on Covid- 19 and this ratio was $90.6 \%$ among nonphysician HCWs $(P=0.058, \chi 2=3.595)$.

Table 1 presents the sociodemographic characteristics of the whole participants and the comparison of physicians to non-physician HCWs.

Table 1. Sociodemographic characteristics in Physician versus Non-physician HCWs 


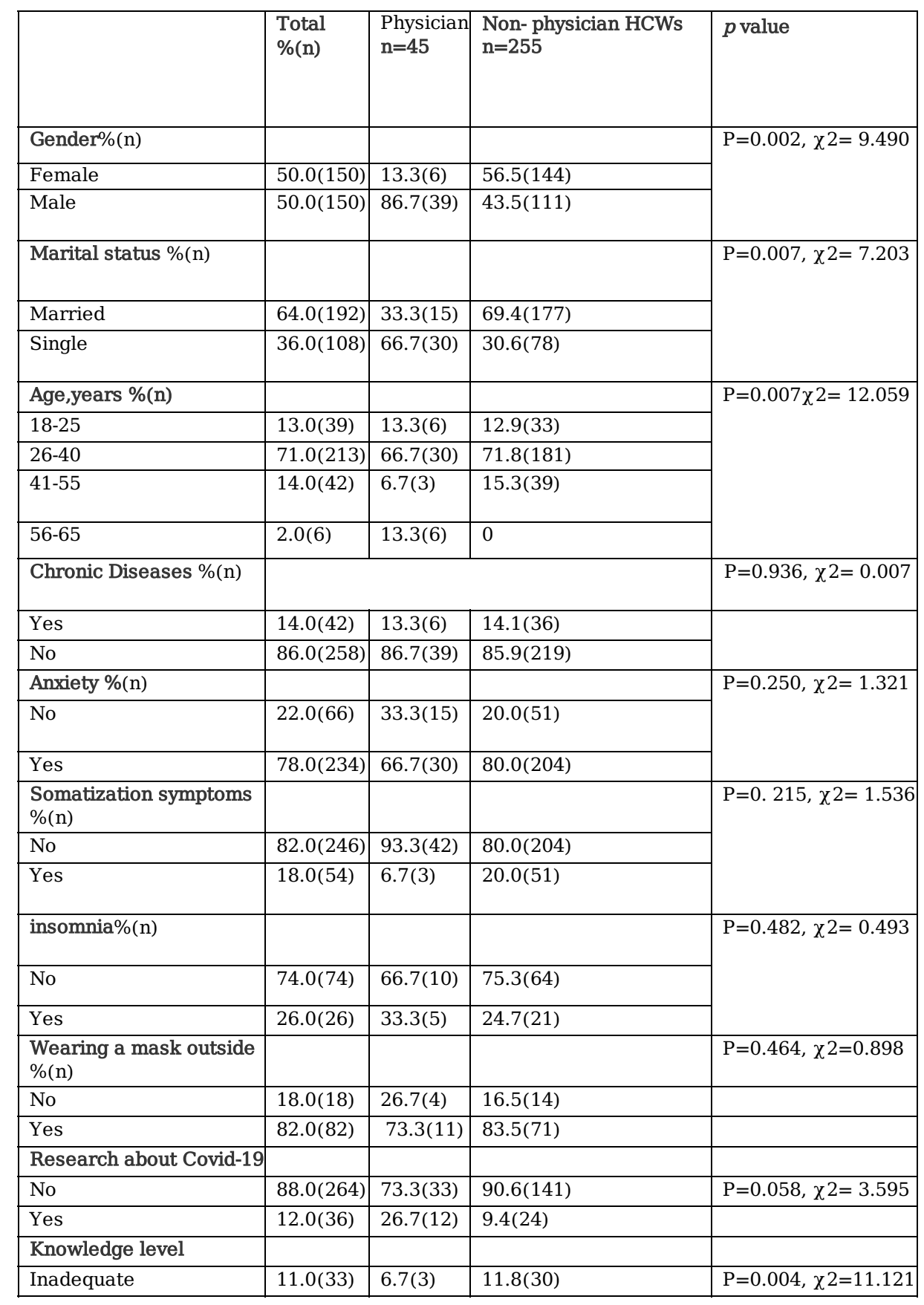

\begin{tabular}{|l|l|l|l|}
\hline Adequate & $68.0(204)$ & $40.0(18)$ & $72.9(186)$ \\
\hline At expert level & $21.0(63)$ & $53.3(24)$ & $15.3(39)$ \\
\hline
\end{tabular}

$\chi 2$ : Pearson Chi-square test

\section{Information and anxiety sources of HCWs about Covid-19:}

Of participants feeling concerned, $62.8 \%$ were between 26 and 40 years old $(P=0.009, \chi 2=11.520)$. There was no significant difference between the professions of HCWs and concern feelings $(P=0.250, \chi 2=1.321)$. Of HCWs, only $0.8 \%$ took psychological support from a therapist or psychiatrist. The HCWs are most concerned about was that "the elderly and other risky population was being infected", which is $37.9 \%$; on the other hand, the concern of being self-infected was only $3,1 \%$. However, there was no significant difference between the concerned feeling of HCWs and what they were anxious about $(P=0.294, \chi 2=10.740)$.

Most HCWs had changed their thoughts about Covid-19 according to what they had learned from their friends and family members (25.4\%) and from the WHO and other health agencies (20.8\%.). The effects on changing their thoughts of newspapers and the press were only $1 \%$. 
$89.2 \%$ of HCW who felt the concern stated that they had changed their thoughts with the information they got from television $(P=0.005, \chi 2=$ 20.271).

Responses of HCWs about the COVID-19 outbreak according to concern statements are shown in Table 2.

Table 2. Responses of health-care workers to concern statements about the COVID-19 outbreak

\begin{tabular}{|c|c|c|c|c|c|c|c|}
\hline \multirow{3}{*}{ Questions } & \multirow{3}{*}{ Characteristics } & & \multicolumn{4}{|c|}{ Concern } & \multirow[t]{3}{*}{$\mathrm{P}$ value } \\
\hline & & \multirow[t]{2}{*}{$\begin{array}{l}\text { Total \% } \\
\text { (n) }\end{array}$} & \multicolumn{2}{|c|}{$\begin{array}{l}\text { No, } \\
(n=66)\end{array}$} & \multicolumn{2}{|c|}{$\begin{array}{l}\text { Yes } \\
(n=234)\end{array}$} & \\
\hline & & & $\mathrm{n}$ & $\%$ & $\mathrm{n}$ & $\%$ & \\
\hline \multirow[t]{2}{*}{ Profession } & Physician & $15(45)$ & 15 & 33.3 & 30 & 66.7 & \multirow[t]{2}{*}{$\begin{array}{l}\mathrm{P}=0.250, \chi^{2}= \\
1.321\end{array}$} \\
\hline & $\begin{array}{l}\text { Nurse and other } \\
\text { staff }\end{array}$ & $85(255)$ & 51 & 20.0 & 204 & 80.0 & \\
\hline \multirow[t]{4}{*}{ Age } & $18-25$ years & 13(39 & 0 & 0 & 39 & $16.7 \%$ & \multirow{4}{*}{$\begin{array}{l}P=0.009 \\
\chi 2= \\
11.520\end{array}$} \\
\hline & $26-40$ years & $71(213$ & 66 & 100 & 147 & $62.8 \%$ & \\
\hline & 41-55 years & $14(42$ & 0 & 0 & 42 & $17.9 \%$ & \\
\hline & 56-65 years & $2(6)$ & 0 & 0 & 6 & $2.6 \%$ & \\
\hline \multirow{7}{*}{$\begin{array}{l}\text { Which factors have changed our feelings against } \\
\text { coronavirus?* }\end{array}$} & Friends, family & $25.4(150)$ & 27 & 18.0 & 123 & 82.0 & \multirow{7}{*}{$\begin{array}{l}\mathrm{P}<0.001, \chi 2= \\
20.271\end{array}$} \\
\hline & Health web sites & $16.2(96)$ & 27 & 28.1 & 69 & 71.9 & \\
\hline & TV & 18.8111) & 12 & 10.8 & 99 & 89.2 & \\
\hline & WHO & $20.8(123)$ & 21 & 17.1 & 102 & 82.9 & \\
\hline & $\begin{array}{l}\text { Online health } \\
\text { programs }\end{array}$ & $3.6(21)$ & 12 & 57.1 & 9 & 42.9 & \\
\hline & $\begin{array}{l}\text { Social media and } \\
\text { internet } \\
\text { browsers }\end{array}$ & $14.2(54)$ & 15 & 17.9 & 69 & 82.1 & \\
\hline & $\begin{array}{l}\text { Newspapers and } \\
\text { journals }\end{array}$ & $1.0(6)$ & 6 & 100.0 & 0 & 0 & \\
\hline \multirow{9}{*}{$\begin{array}{l}\text { What are the situations we are most anxious about due } \\
\text { to Covid-19 outbreak?* }\end{array}$} & Economy & $20.3(138)$ & 45 & 32.6 & 63 & 67.4 & \multirow{9}{*}{$\begin{array}{l}\mathrm{p}=0.294, \chi^{2}= \\
10.740\end{array}$} \\
\hline & $\begin{array}{l}\text { Childs' being } \\
\text { infected }\end{array}$ & $21.6(147)$ & 33 & 22.4 & 114 & 77.6 & \\
\hline & $\begin{array}{l}\text { Elderly and risky } \\
\text { populations } \\
\text { being infected }\end{array}$ & $37.9(258)$ & 54 & 20.9 & 104 & 79.1 & \\
\hline & Fast spreading & $9.7(66)$ & 6 & 9.1 & 60 & 90.9 & \\
\hline & Dying of illness & $2.6(18)$ & 3 & 16.7 & 15 & 83.3 & \\
\hline & $\begin{array}{l}\text { Inadequate medical } \\
\text { facility }\end{array}$ & $3.121)$ & 6 & 28.6 & 15 & 71.4 & \\
\hline & Being quarantined & $0.9(6)$ & 0 & 0 & 6 & 100.0 & \\
\hline & Loss of income & $0.9(6)$ & 3 & 50.0 & 3 & 50.0 & \\
\hline & Being infected & $3.1(21)$ & 3 & 28.6 & 15 & 71.4 & \\
\hline \multirow[t]{4}{*}{$\begin{array}{l}\text { What have you done to support your mental and } \\
\text { emotional health during Covid-19 outbreak?* }\end{array}$} & $\begin{array}{l}\text { Gathering } \\
\text { information and } \\
\text { doing research }\end{array}$ & $33.9(129)$ & 39 & 30.2 & 90 & 69.8 & \multirow{4}{*}{$\begin{array}{l}\mathrm{P}<0.05 \\
\chi 2= \\
15.449\end{array}$} \\
\hline & $\begin{array}{l}\text { Asking specialists } \\
\text { for } \\
\text { information }\end{array}$ & $8.7(33)$ & 0 & 0 & 33 & 100.0 & \\
\hline & $\begin{array}{l}\text { Getting } \\
\text { Psychological } \\
\text { support }\end{array}$ & $0.8(3)$ & 3 & 100.0 & 0 & .0 & \\
\hline & Taking medicine & $2.4(9)$ & 3 & 33.3 & 6 & 66.7 & \\
\hline
\end{tabular}




\begin{tabular}{||l|l|l|l|l|l||}
\hline Using social media a lot more & $20.5(78)$ & 9 & 11.5 & 69 & 88.5 \\
\hline Suspending social media & $5.5(21)$ & 9 & 42.9 & 12 & 57.1 \\
\hline Doing exercise & $17.3(66)$ & 18 & 27.3 & 48 & 72.7 \\
\hline Allocating time to my hobbies & $11.0(42)$ & 6 & 14.3 & 36 & 85.7 \\
\hline
\end{tabular}

*Multiple responses, WHO: World Health Organization, TV: television

\section{The attitudes and behaviors of HCWs about Covid-19 pandemic:}

In our study, only $6.7 \%$ of HCWs had no anxiety of any kind during the Covid-19 pandemic. Among HCWs, the physicians had stated that they felt very anxious about the spreading of the Covid- 19 pandemic and this anxiety level was significantly higher $(\% 80$ vs $\% 47.1, p=0.006$ $\left.\chi^{2}=12.591\right)$.

Of HCWs, $60 \%$ thought that Covid-19 had affected their daily life very much as strongly agree, $49 \%$ thought that their future life would be affected and $59 \%$ thought it had affected their social relations.

When answers in terms of affecting daily life, future life, and social relations are considered according to professions, there was no statistically significant difference between the physicians and non-physician HCWs $(p=0.104, p=0.100, p=0.038$, respectively, Table 3)

Because of the outbreak, $72 \%$ of HCWs did not choose mass transport. of HCWs, $75 \%$ said that their handwashing habits increased very much in frequency. $85 \%$ stated that they obeyed the precautions such as social distance. All those who did not believe that the social distance rule was protective, were non-physician health workers and this rate was only $1.2 \%$. When answers of questions including mass transport, handwashing, and social distance are considered according to professions, there was no statistically significant difference between the physicians and non-physician HCWs $(p=0.089, p=0.085, p=0.212$, respectively, Table 3$)$

Table 3. The attitudes and behaviors of HCWs about Covid-19 pandemic 


\begin{tabular}{|c|c|c|c|c|c|c|c|c|c|}
\hline \multirow[b]{2}{*}{ Questions \% (n) } & \multicolumn{4}{|c|}{$\begin{array}{l}\text { Physician } \\
(\mathrm{n}=45)\end{array}$} & \multicolumn{4}{|c|}{$\begin{array}{c}\text { Non- } \\
\text { physician } \\
\text { HCWs } \\
(\mathrm{n}=255)\end{array}$} & \multirow[t]{2}{*}{ P value, $\chi^{2}$} \\
\hline & Disagree & $\begin{array}{l}\text { Neither agree } \\
\text { nor disagree }\end{array}$ & Agree & Strongly agree & Disagree & $\begin{array}{l}\text { Neither } \\
\text { agree } \\
\text { nor } \\
\text { disagree }\end{array}$ & Agree & $\begin{array}{l}\text { Strongly } \\
\text { agree }\end{array}$ & \\
\hline $\begin{array}{l}\text { I think that Covid-19 } \\
\text { had affected their } \\
\text { daily life very much }\end{array}$ & $6.7(3)$ & 13.3(6) & $20.0(9)$ & $60(27)$ & 0 & $10.6(27)$ & $29.4(75)$ & $60.0(153)$ & $\begin{array}{l}p=0.104 \\
\chi 2=6.157\end{array}$ \\
\hline $\begin{array}{l}\text { I think that our } \\
\text { future life would be } \\
\text { affected }\end{array}$ & $6.7(3$ & $40.0(18)$ & $40.0(18$ & 13.3(6) & 0 & $23.5(60)$ & $50.6(129)$ & $25.9(266)$ & $\begin{array}{l}\mathrm{p}=0.100 \\
\chi 2=6.249\end{array}$ \\
\hline $\begin{array}{l}\text { I think that it had } \\
\text { deeply affected } \\
\text { social relations }\end{array}$ & $6.7(3)$ & 0 & $20.0(9)$ & $73.3(33)$ & 0 & $8.2(21)$ & $35.3(90)$ & $56.5(144)$ & $\begin{array}{l}\mathrm{p}=0.038 \\
\chi 2=8.420\end{array}$ \\
\hline $\begin{array}{l}\text { I think that my } \\
\text { anxiety level had } \\
\text { increased very much } \\
\text { since the Covid-19 } \\
\text { outbreak had } \\
\text { emerged. }\end{array}$ & $6.7(3)$ & $6.7(3)$ & $80.0(36)$ & $6.7(3)$ & 0 & $29.4(75)$ & $47.1(120)$ & $23.5(60)$ & $\begin{array}{l}\mathrm{p}= \\
0.006, \chi 2=12.591\end{array}$ \\
\hline $\begin{array}{l}\text { I think that my } \\
\text { handwashing } \\
\text { frequency had } \\
\text { increased very } \\
\text { much } \\
\text { outside the hospital }\end{array}$ & 0 & 13.3(6) & $80.0(36)$ & $6.7(3)$ & $1.2(3)$ & $24.7(63)$ & $74.1(189)$ & 0 & $\begin{array}{l}\mathrm{p}= \\
0.085, \chi 2=6.619\end{array}$ \\
\hline $\begin{array}{l}\text { I think that } 1 \text { had } \\
\text { to maintain } \\
\text { social/personal } \\
\text { distance }\end{array}$ & 0 & $13.3(6)$ & 13.3(6) & $73.3(33)$ & $1.2(3$ & $2.4(6)$ & $9.4(24$ & $87.1(222)$ & $\begin{array}{l}\mathrm{p}= \\
0.212, \times 2=4.498\end{array}$ \\
\hline $\begin{array}{l}\text { I think that I had } \\
\text { to buy extra food }\end{array}$ & $26.7(12)$ & 0 & $33.3(15)$ & $40.0(18)$ & $15.3(39)$ & $22.4(57)$ & $18.8(48)$ & $43.5(111)$ & $\begin{array}{l}\mathrm{p}= \\
0.294, \chi 2=3.712\end{array}$ \\
\hline $\begin{array}{l}\text { I think that I had } \\
\text { to buy extra } \\
\text { cleaning supplies. }\end{array}$ & $20.0(9)$ & 0 & $6.7(3)$ & $73.3(33)$ & $21.2(54)$ & $8.2(21)$ & $8.2(21)$ & $62.4(159)$ & $\begin{array}{l}p=0.677 \\
\chi 2=1.523\end{array}$ \\
\hline $\begin{array}{l}\text { I think that I had to } \\
\text { wear a } \\
\text { mask outdoors }\end{array}$ & $6.7(3)$ & $6.7(3)$ & $13.3(6)$ & 73.3(33) & $3.5(9)$ & $4.7(12)$ & $8.2(21)$ & 83.5(213) & $\begin{array}{l}P=0.815 \\
\chi 2=0.942\end{array}$ \\
\hline
\end{tabular}

\begin{tabular}{|c|c|c|c|c|c|c|c|c|c|}
\hline $\begin{array}{l}\text { I am sure that the precautions I } \\
\text { had taken } \\
\text { were preventive enough. }\end{array}$ & 13.3(6) & $26.7(12)$ & $40.0(18)$ & $20.0(9)$ & $9.4(24)$ & $18.8(48)$ & $55.3(141)$ & $16.5(42)$ & $\begin{array}{l}\mathrm{p}=0.742 \\
\chi 2=1.244\end{array}$ \\
\hline $\begin{array}{l}\text { I think that I had to minimize } \\
\text { my choice of } \\
\text { mass transport }\end{array}$ & 0 & 20.0() & 13.3(6) & $66.7(30)$ & $1.2(3)$ & $3.5(9)$ & $22.4(57)$ & $72.9(186)$ & $\begin{array}{l}\mathrm{p}= \\
0.089, \chi 2=6.505\end{array}$ \\
\hline $\begin{array}{l}\text { My interest in patients who } \\
\text { came for routine examination } \\
\text { has } \\
\text { diminished }\end{array}$ & $46.7(21)$ & $26.7(12)$ & $20.0(9$ & $6.7(3)$ & $18.8(48)$ & $49.4(126)$ & $23.5(60)$ & $8.2(21)$ & $\begin{array}{l}\mathrm{P}=0.077 \\
\chi 2=6.840\end{array}$ \\
\hline $\begin{array}{l}\text { My feelings about having } \\
\text { a risky occupation have increased }\end{array}$ & 0 & $6.7(3)$ & $6.7(3)$ & $86.7(39)$ & $4.7(12)$ & $2.4(6)$ & $29.4(75)$ & $63.5(162)$ & $\begin{array}{l}\mathrm{p}= \\
0.168, \chi 2=5.052\end{array}$ \\
\hline
\end{tabular}

Because of the outbreak, $43 \%$ of HCWs bought extra food and $64 \%$ bought extra cleaning supplies and stored at home. $26.7 \%$ of physicians stated that there was no need to buy extra food and $21.2 \%$ of non-physician HCWs said that they had no intention to buy extra cleaning supplies. However, there was no statistically significant difference between the answers given by physicians and the other HCWs ( $p=0.294, p=$ 0.677 , respectively).

Of HCWs, $82 \%$ responded that they wore masks outside the hospital since the outbreak had emerged. $73.3 \%$ of physicians and $83.5 \%$ of other HCWs agreed on the importance of wearing a mask outside the hospital. There was no significant difference between HCWs concerning wearing masks outside $(p=0.815)$. 
Of HCWs, $17 \%$ were certain about the preventiveness of precautions they had taken; on the other hand, $10 \%$ were not sure. $13.3 \%$ of participants who thought that the preventive measures taken were inadequate were physicians and $9.4 \%$ were the rest of HCWs other than physicians. There was no difference between the two groups concerning their thoughts on the protectiveness of the precautions taken ( $p=$ 0.742).

Of HCWs, 45\% replied that their interest in patients who came for routine examination had not changed at all. Physicians stated that their interest in patients who came for routine examination had not changed by $46.7 \%$ and this percentage was $18.8 \%$ for the rest of the participants.

Of HCWs, $67 \%$ considered that their feeling about being in a risky occupation as an HCW had increased after the COVID-19 pandemic. $86.7 \%$ of the physicians strongly agreed with this consideration, but this rate was $62.7 \%$ for other HCWs. Hovewer, there was no significant difference between the groups $(\mathrm{p}=0.168)$. Distribution of attitudes and behaviors of physicians and non-physician HCWs concerning Covid-19 was shown in Table 3.

\section{The opinion of HCWs about the preventive measures the government has taken:}

Of HCWs, $46 \%$ stated that they were satisfied with the governmental precautions during Covid- 19 pandemic; $56 \%$ agreed that some precautions had been taken, but criticized its inadequacy. Concerning governmental preventive measures, $66.7 \%$ of physicians were satisfied, $13.3 \%$ were extremely satisfied and $42.4 \%$ of non-physician HCWs were satisfied and $12.8 \%$ were extremely satisfied.

Of HCWs, 45\% thought that the government had announced the latest data to the public whereas \%11 thought that they had not done it adequately. $58 \%$ thought that the government adequately announced the transmission routes during the pandemic.

Of HCWs, $65 \%$ agreed that during pandemic the governmental policy of quarantine, travel restrictions, and closing some borders were sufficient. $43 \%$ thought that an adequate number of tests had been performed, whereas; $41 \%$ thought the opposite. $53.3 \%$ of physicians thought that the number of tests being performed was sufficient enough but, $45.9 \%$ of non-physician HCWs did not agree ( $p=0.030$ OR:0.29-0.35 $\chi 2$ : 7.047) (Table 4).

Table 4. Opinions of HCWs about governmental precautions against Covid-19

\begin{tabular}{|c|c|c|c|c|c|c|c|c|c|}
\hline \multirow[b]{2}{*}{ Questions, \% (n) } & \multicolumn{4}{|c|}{$\begin{array}{l}\text { Physician } \\
(n=45)\end{array}$} & \multicolumn{4}{|c|}{$\begin{array}{c}\text { Non- } \\
\text { physician } \\
\text { HCWs } \\
(\mathrm{n}=255)\end{array}$} & \multirow[t]{2}{*}{$\begin{array}{c}\text { P-value } \\
\chi^{2}\end{array}$} \\
\hline & Disagree & $\begin{array}{l}\text { Neither agree } \\
\text { nor disagree }\end{array}$ & Agree & $\begin{array}{l}\text { Strongly } \\
\text { agree }\end{array}$ & Disagree & $\begin{array}{l}\text { Neither } \\
\text { agree } \\
\text { nor } \\
\text { disagree }\end{array}$ & Agree & $\begin{array}{l}\text { Strongly } \\
\text { agree }\end{array}$ & \\
\hline $\begin{array}{l}\text { I am satisfied } \\
\text { with overall } \\
\text { governmental } \\
\text { policy }\end{array}$ & $6.7(3)$ & $13.3(6)$ & $66.7(30)$ & $13.3(6)$ & $9.4(24)$ & $29.4(75$ & $42.4(108)$ & $18.8(48)$ & $\begin{array}{l}\mathrm{p}=0.365 \\
\chi^{2}=3.180\end{array}$ \\
\hline $\begin{array}{l}\text { The government had } \\
\text { taken enough } \\
\text { precautions to prevent } \\
\text { the spreading of the } \\
\text { disease }\end{array}$ & $6.7(3)$ & $60.0(27)$ & $26.7(12$ & $6.7(3)$ & $10.6(27)$ & $55.3(141)$ & $24.7(63)$ & $9.4(24)$ & $\begin{array}{l}\mathrm{p}=0.946 \\
\chi^{2}=0.373\end{array}$ \\
\hline $\begin{array}{l}\text { The government had } \\
\text { done enough travel } \\
\text { restrictions and } \\
\text { quarantine }\end{array}$ & $20.0(9)$ & 0 & $80.0(36)$ & 0 & $16.5(42)$ & 0 & 62.4(159) & $21.2(54)$ & $\begin{array}{l}p=0.144 \\
\chi 2=3.881\end{array}$ \\
\hline $\begin{array}{l}\text { The government had } \\
\text { done enough to } \\
\text { communicate publicly } \\
\text { about the latest news }\end{array}$ & $13.3(6)$ & $20.0(9)$ & $60.0(27)$ & $6.7(3)$ & $10.6(27)$ & $31.8(81)$ & $42.4(108)$ & 15.3(39) & $\begin{array}{l}p=0.525 \\
\chi^{2}=2.236\end{array}$ \\
\hline $\begin{array}{l}\text { The government had } \\
\text { done enough to } \\
\text { inform the public about } \\
\text { transmission routes of } \\
\text { COVID-19 }\end{array}$ & $6.7(3)$ & 0 & $53.3(24)$ & $40.0(18)$ & 0 & $8.2(21)$ & 58.8(150) & $32.9(54)$ & $\begin{array}{l}p=0.864 \\
\chi 2=0.292\end{array}$ \\
\hline $\begin{array}{l}\text { The government had } \\
\text { done enough Covid- } \\
19 \text { tests }\end{array}$ & $13.3(6)$ & $33.3(15)$ & $53.3(24)$ & 0 & $45.9(117)$ & $12.9(33)$ & $41.2(105)$ & 0 & $\begin{array}{l}\mathrm{P}=0.030 \\
\chi 2=7.047\end{array}$ \\
\hline
\end{tabular}


Among the questions classified to determine the psychological status for all HCWs, the "feeling of being infected with Covid-19" item had the highest mean total score with $2.60 \pm 0.97$, and " The feeling of a decrease in the joy of living" item had the lowest mean total score with $0.92 \pm 1.09$.

The mean score of "feeling nervous/anxious/on edge item" was $2.53 \pm 0.52$ for physicians, and $2.26 \pm 0.86$ for non-physician HCWs. This difference was not statistically significant between the two groups. (mean dif $=0,28,95 \%$ confidence interval $=-0.06$ to $0.61 p=0.102$ )

For all HCWs, the mean total score of "Feeling of increased body pain and agony" item was $0.69 \pm 1.19$. The mean "Feeling of increased body pain and agony" item score for non-physician HCWs was higher than physicians $(0.27 \pm 0.80$ vs $0.76 \pm 1.23$; mean dif $=-0.50,95 \%$ confidence interval=-1.002 to $0.006, p<0.05)$.

Tabe 5 presents scores of mental health variables for psychological conditions of HCWs during Covid-19 according to two groups.

Table 5. The mean scoring system values for Psychological manifestations item according to physicians and non-physician healthcare workers

\begin{tabular}{|l|l|l|l|l|}
\hline Questions related Psychological manifestations & Total & Physician (n=45) & $\begin{array}{l}\text { Non- physicia } n \text { HCWs } \\
\text { (n=255) }\end{array}$ & P value \\
& & & & \\
\hline Feeling nervous/anxious/on edge & & & $2.26 \pm 0.86$ & 0.10 \\
\hline Not being able to stop worrying & $2.01 \pm 0.69$ & $2.53 \pm 0.52$ & $2.35 \pm 1.17$ & 0.22 \\
\hline Loss of joy of living & $2.29 \pm 1.21$ & $1.93 \pm 1.44$ & $0.95 \pm 1.02$ & 0.14 \\
\hline Feeling of being infected with covid-19 & $0.92 \pm 1.09$ & $0.53 \pm 0.92$ & $2.55 \pm 1.05$ & 0.70 \\
\hline Feeling of avoidance from crowds & $2.60 \pm 0.97$ & $2.67 \pm 0.90$ & $1.34 \pm 0.63$ & 0.75 \\
\hline Loss of interest in following news & $0.92 \pm 1.09$ & $1.40 \pm 0.74$ & $2.41 \pm 1.07$ & 0.69 \\
\hline Difficulty in falling asleep & $2.43 \pm 1.07$ & $2.53 \pm 1.06$ & $0.95 \pm 1.30$ & 0.40 \\
\hline Feeling of increased body pain and agony & $1.00 \pm 1.31$ & $1.27 \pm 1.39$ & $0.76 \pm 1.23$ & $<0.05$ \\
\hline Feeling down/depressed/hopeless & $0.69 \pm 1.19$ & $0.27 \pm 0.80$ & $1.94 \pm 0.73$ & 0.71 \\
\hline
\end{tabular}

\section{Discussion}

This is the first study on HCWs regarding the behavioral effects and level of psychological distress of the Covid-19 pandemic and reflecting their thoughts about governmental policies and practices.

Jianbo Lai et al. (6) demonstrated in their study including 1257 Chinese HCWs that the majority of the HCWs showed anxiety, depression, and sleep disorder symptoms, and more than $70 \%$ reported psychological problems during corona 19 pandemic. In a study conducted in 2016 by Abdullah J. Alsahafi et al. (7) participants' source of information was the Ministry of Health during MERS-coronavirus (MERS-CoV) (\% 74.3). According to a survey performed by Khan et al. the main source of information was reported as the internet (8). In our study information sources of HCWs were family (25.4\%), WHO and other health agencies (20.8\%), printed media such as newspapers and journals (1\%), television $18.8 \%$, and social media $(14.2 \%)$.

Lei et al. (9) studied about 1593 Chinese people during the Covid-19 pandemic which resulted that society felt more anxiety about being infected, having no psychological support, and facing more financial damage. We also found that the HCWs were most anxious about infecting the elder and susceptible ones in their family, then came the children's being infected and thirdly economic loss.

According to the study of Khan et al. during the MERS-CoV outbreak in Saudi Arabia, most of the HCWs told that they took precautions using gloves, laboratory coats, and personal protective equipment but they believed that these precautions would not reduce the prevalence of MERSCOV (8). In our study the participants also took precautions against infection; nevertheless, they thought that these precautions would reduce the spreading of Covid-19.

In the study conducted by Khan et al. in Saudi Arabia during MERS-CoV outbreak, it was demonstrated that HCWs showed a positive attitude and concrete knowledge against MERS. Yet, there were situations the HCWs showed negative attitudes and inadequate knowledge (8).

Similarly, $33.9 \%$ of the participants provided psychological support via trying to gather information, and only $0.8 \%$ interviewed with a therapist or psychiatrist in our study.

Rima Styra et al. performed a study in 2008 during the SARS outbreak which revealed that HCWs had high-stress levels even they had cared only for one patient (10). We also have founded similar anxiety and stress levels among more than half of HCWs during Covid-19. 
Bukhari et al. (11) reported that there were very high anxiety levels among nurses during MERS. Most of the HCWs enrolled in our study also were very anxious during Covid-19 pandemic and what they were more anxious about was the risk of infecting elderly and fragile people, yet they were less anxious about being infected. Wang et al. reported that more than half of the normal population enrolled to study also experienced moderate to severe psychological effects. Most of the participants washed their hands with soap after touching contaminated objects, closed their mouths during sneezing or coughing, and wore a mask regardless of symptoms patients had. Very beginning of Covid-19 outbreak in China, the internet had become the main information channel (93.5\%) (12).

We also found that the HCWs' frequency of hand-washing and wearing masks both inside and outside the hospital increased remarkably. In our study, the main information channel of HCWs was not the internet but WHO and other health agencies.

According to Wen et al. very serious psychological problems had emerged in the society during Covid-19 pandemic and they concluded that it is required to inform the public and follow appropriate strategies (13). We similarly found that Covid-19 pandemic had deeply affected most of the HCWs' daily life and social relationships and that they were very anxious. A survey consisting of 10754 Iranians showed that the severity of anxiety symptoms was normal in $49.1 \%$, severe in $9.3 \%$, and very severe in $9.8 \%$ of the participants. Anxiety levels were significantly higher in females than in males. Although Covid-19 related infection and mortality rates seemed to increase with older age, this study showed that anxiety levels were much higher in the 21-40 age group (14). The anxiety level was higher in our study and $53 \%$ of participants had severe anxiety. There was no difference between the two genders.

Research on mental health problems in medical health workers during COVID-19 epidemic is limited. Zhang et al (15) found that compared with nonmedical health workers, medical health workers had higher total Patient Health Questionnaire-4 scores. In our study, both physicians and non-physicians HCWs were feeling nervous/anxious/on edge largely and the highest anxiety score for all healthcare professionals is the feeling of getting covid-19 according to Patient Health Questionnaire-4 (PHQ-4) and the Turkish Beck Depression Scale.

\section{Limitation:}

The most prominent limitation of this survey is the limited study population. However, this study has exhibited some important results because it's being one-to-one and a face-to-face interview with HCWs working very long hours during Covid-19. Another limitation is that no analysis of potential risk factors which might cause obsessive-compulsive disease, depression, anxiety, and somatization disorder could not be performed.

\section{Conclusion}

The results of this survey study showed that the issue that healthcare professionals worry most about was the infection of elderly and risky patients. Concerned HCWs were most likely to receive Covid-19 related information from television. Physicians worry more about covid- 19 spread than other healthcare professionals and think the Covid-19 test has been performed adequately. When their psychological status is evaluated, the highest anxiety score for all healthcare professionals is the feeling of getting covid-19. Both physicians and non-physicians HCWs were feeling nervous/anxious/on edge largely. Non-physicians HCWs feel more body pain and agony. During Covid-19 pandemic, healthcare workers did not seek enough psychological support. HCWs had felt anxiety in their work environment during Covid-19 pandemic such as it had been the issue in previous pandemics, MERS, and SARS. We observed that increased anxiety levels of HCWs reduced their care for patients, quality of life, and caused negative feelings of such as working in a risky job and infecting other people. We pointed out that HCWs should be completely informed via education programs including transmission paths, infection control measures, and programs that help reducing anxiety levels so that HCWs would efficiently struggle with a pandemic. We need such more studies to maintain a concrete fight with pandemic all around the world.

\section{Declarations}

\section{Conflict of Interest}

We have no potential conflict of interest.

\section{References}

1. The WHO MERS-CoVResearchGroup. State of Knowledge anddatagaps of Middle East RespiratorySyndromeCoronavirus (MERS-CoV) in humans. PLoSCurr 2013;5 pii: ecurrents. outbreaks.0bf719e352e7478f8ad85fa30127ddb8 2013 Nov 12;5.

2. https://covid19.saglik.gov.tr/

3. Lu R, Yu X, Wang W, et al. Characterization of humanccoronacvirusetiology in Chineseadultswithadultswithacuteupperrespiratorytractinfectionbyreal-time RT-PCR assays. PLoSOne 2012;7(6):e38638.

4. Al-Tawfiq JA. Middle East respiratory syndrome- coronavirus infection: an overview. J Infect Public Health 2013;6(5):319-2 
5. Zaki AM, van Boheemen S, Bestebroer TM, Osterhaus AD,Fouchier Isolation of a novel coronavirus from a man with pneumonia in Saudi Arabia. N Engl J Med 2012;367(19):1814-

6. JianboLai , SimengMa, YingWang ,Zhongxiang Cai , Jianbo Hu , NingWei , JiangWu, et Factors Associated With Mental Health Outcomes Among Health Care Workers Exposed to Coronavirus Disease 2019 JAMA Netw Open. 2020;3(3):e203976. doi:10.1001/jamanetworkopen.2020.3976

7. Abdullah J. Alsahafi, Allen C. Cheng. Knowledge, Attitudes and Behaviours of Healthcare Workers in the Kingdom of Saudi Arabia to MERS Coronavirusand Other Emerging Infectious Diseases, international journal of environmental research and public healthy, Published: 6 December 2016

8. Khan MU, Shah S, Ahmad A, Fatokun O. Knowledge and attitude of health care workers about middleeast respiratory syndrome in multi special tyhospitals of Qassim, SaudiArabia. BMC Public Health. 2014;14(1):1.

9. Lei L, Huang X, Zhang S, Yang J, Yang L, Xu M.Comparison of PrevalenceandAssociatedFactors of Anxiety andDepressionAmong People Affectedbyversus People Unaffectedby Quarantine Duringthe COVID-19 Epidemic in Southwestern China.Med Sci Monit. 2020 Apr 26;26:e924609. doi: 12659/MSM.924609.

10. Rima Styra, Laura Hawryluck, Susan Robinson, SonjaKasapinovic, CalvinFones, andWayne L. Gold. Impact on health care workers employed in high-risk areas during the Toronto SARS outbreak, J Psychosom Res. 2008 Feb; 64(2): 177-183.

11. Bukhari EE, Temsah MH, Aleyadhy AA, Alrabiaa AA, Alhboob AA, Jamal AA, Binsaeed AA. Middle East respiratorys yndrome coronavirus (MERS-CoV) outbreak perceptions of risk and stres evaluation in nurses. J Infect Dev Ctries. 2016 Aug 31;10(8):845-50. doi: 10.3855/jidc.69255)

12. Wang C1, Pan R1, Wan X1, Tan Y1, Xu L1, Ho CS2,3, Ho RC1,3,4. ImmediatePsychologicalResponsesandAssociatedFactorsduringthelnitialStage of the 2019 CoronavirusDisease (COVID-19) Epidemicamongthe General Population in Chinalnt J EnvironResPublicHealth. 2020 Mar; 17(5): 1729.

13. Wen Li, ${ }^{*} Y u a n$ Yang,1,2,3,*Zi-Han Liu,1,2, ${ }^{\star}$ Yan-Jie Zhao,1,2,*Qinge Zhang,4, ${ }^{*}$ Ling Zhang,4, ${ }^{*}$ Teris Cheung,5andYu-Tao Xiang1,2,Progression of MentalHealth Services during the COVID-19 Outbreak in China, Int J Biosci. 2020; 16(10): 1732-1738.

14. Moghanibashi-Mansourieh A.Assessing the anxiety level of Iranian general population during COVID-19 outbreak.Asian J Psychiatr. 2020 Apr 18;51:102076. doi: 10.1016/j.ajp.2020.102076. [Epubahead of print].

15. Zhang WR, Wang K, Yin L, et al. Mental Health and Psychosocial Problems of MedicalHealth Workers during the COVID-19 Epidemic in China [published online ahead of print, 2020 Apr 9]. Psychother Psychosom. 2020;1- DOI:10.1159/000507639 